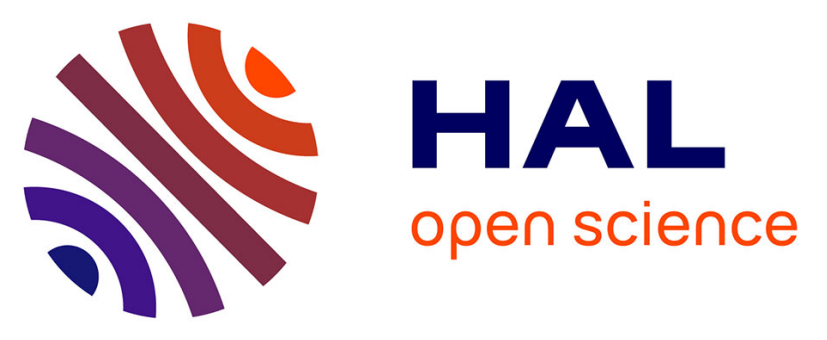

\title{
Stable isotope characterization of pedogenic and lacustrine carbonates from the Chinese Tian Shan: constraints on the Mesozoic - Lower Cenozoic palaeo-environmental evolution
}

Gloria Heilbronn, Philippe Boulvais, E Marchand, Cécile Robin, Sylvie

Bourquin, Laurie Barrier, Y Jia, B. Fu, Marc Jolivet

\section{To cite this version:}

Gloria Heilbronn, Philippe Boulvais, E Marchand, Cécile Robin, Sylvie Bourquin, et al.. Stable isotope characterization of pedogenic and lacustrine carbonates from the Chinese Tian Shan: constraints on the Mesozoic - Lower Cenozoic palaeo-environmental evolution. Chemie der Erde / Geochemistry, 2015, 75 (1), pp.133-141. 10.1016/j.chemer.2014.11.004 . insu-01116934

\section{HAL Id: insu-01116934 \\ https://hal-insu.archives-ouvertes.fr/insu-01116934}

Submitted on 22 Jun 2015

HAL is a multi-disciplinary open access archive for the deposit and dissemination of scientific research documents, whether they are published or not. The documents may come from teaching and research institutions in France or abroad, or from public or private research centers.
L'archive ouverte pluridisciplinaire HAL, est destinée au dépôt et à la diffusion de documents scientifiques de niveau recherche, publiés ou non, émanant des établissements d'enseignement et de recherche français ou étrangers, des laboratoires publics ou privés. 
Stable isotope characterization of pedogenic and lacustrine carbonates from the Chinese Tian Shan: constraints on the Mesozoic - Lower Cenozoic palaeo-environmental evolution

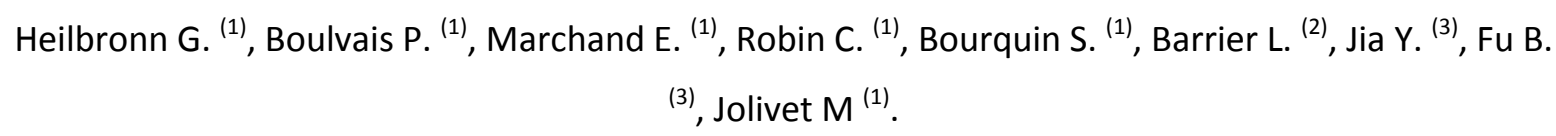

(1) Géosciences Rennes, Observatoire des Sciences de I'Univers de Rennes, UMR 6118 CNRS Univ. Rennes 1, Rennes, France.

(2) Institut de Physique du Globe de Paris, Sorbonne Paris Cité, Université Paris Diderot, UMR CNRS 7154, 1 rue Jussieu, F-75005 Paris, France.

(3) Center for Earth Observation and Digital Earth, Chinese Academy of Sciences, Beijing, China.

To be submitted to Chemie der Erde

\section{Abstract}

In the Mesozoic-Cenozoic continental deposits of the Tian Shan area, two main levels containing pedogenic carbonates have been identified on both the southern and northern foothills of the range: one in the Upper Jurassic series and one in the Upper Cretaceous - Lower Palaeocene series. In order to reconstruct the palaeo-environmental and palaeo-topographic characteristics of the Tian Shan area during these two periods, we measured the oxygen and carbon isotope composition of these pedogenic carbonates (calcrete and nodules). The stable isotope compositions are homogeneous: most $\delta^{18} \mathrm{O}$ values are between 21 and $25 \%$ and most $\delta^{13} \mathrm{C}$ values are between -4 and $-6 \%$. No distinction can be made between the calcrete and nodule isotopic compositions. The constancy of isotopic values across the Tian Shan is evidence of a development of these calcification features in similar palaeo-environmental conditions. The main inference is that no significant relief existed in that area at the Cretaceous - Palaeogene boundary, implying that most of the present relief developed later, during the Cenozoic. In addition to the pedogenic carbonates, few beds of limestones interstratified in the Jurassic series of the southern foothills display oxygen and carbon 
32

isotope compositions typical of lacustrine carbonates, ruling out brackish water incursion at that period in the region.

Keywords: pedogenic carbonates - stable isotopes - Mesozoic palaeo-environment - Tian Shan

\section{Introduction}

Calcification is a ubiquitous phenomenon that occurs in a large variety of geological settings including limestone diagenesis and continental weathering. In continental environments, under semiarid conditions, the interaction between meteoric waters or groundwaters and sedimentary rocks commonly leads to pedogenic calcification (e.g. Wright and Tucker, 1991; Alonso-Zarza, 2003; Hasiotis et al., 2007). The resulting calcareous features correspond to the so-called calcretes and occur as isolated nodules or rather continuous levels of carbonates (Retallack, 1997; Wright, 2008). The oxygen and carbon isotope composition of such neo-formed carbonates provides information on the palaeo-environments within which they precipitated (e.g. Alonso-Zarza, 2003). Indeed, while the oxygen isotope composition of these carbonates depends upon processes taking place in the soil ground water system, such as evaporation, it is also function of the composition of the meteoric water. The later depends on the palaeo-latitude and the palaeo-altitude of the area, as well as on the distance to the ocean from which the atmospheric masses are derived. In a specific region, any variation in the $\delta^{18} \mathrm{O}$ value of the carbonates through time may thus be, for example, a consequence of the climatic evolution. At a specific stratigraphic level, geographic variations of $\delta^{18} \mathrm{O}$ may relate to the existence of a significant palaeo-topography (e.g. Garzione et al., 2000). In a similar way, the carbon isotope composition of continental neo-formed carbonates depends on the source of the carbon in the region, which relates to the relative abundance of carbon-bearing rocks (e.g. marine carbonates) over available organic carbon. The former have $\delta^{13} \mathrm{C}$ values close to $0 \%$, whereas the second source has very negative values, close to $-25 \%$ for carbon derived from C3-type plants and 15\%o from C4-type ones. The $\delta^{13} \mathrm{C}$ signal can thus potentially be related to the geology of the area, the palaeo-flora itself partially controlled by the palaeo-climate (e.g. Pustovoytov, 2002).

In North-West China, the intracontinental, east-west oriented Tian Shan Range (Fig. 1) provides spectacular outcrops of Mesozoic-Cenozoic clastic sediment series. During fieldwork, we recognized several occurrences of calcretes and nodules throughout these series, especially in the Upper Mesozoic and Lower Cenozoic deposits. A strong aridification occurred during Late Jurassic, following 
the progressive appearance of dry seasons since the late Early Jurassic (e.g. Allen et al., 1991; Hendrix et al., 1992; Eberth et al., 2001; Li et al., 2004; Ashraf et al., 2010; Pan et al., 2012). Since this period, arid to semi-arid climate has been predominant in the Tian Shan area (e.g. Allen et al., 1991; Hendrix et al., 1992; Li et al., 2004; Sun and Wang, 2005; Jiang et al., 2008).

Since the late 1970s, the Cenozoic tectonic development of the range and its foreland basins has been widely studied (e.g. Tapponnier and Molnar, 1979; Windley et al., 1990; Allen et al., 1991; Hendrix et al., 1994; Charreau et al., 2005, 2009, 2012; Jolivet et al., 2014). In contrast, the Mesozoic evolution of the Tian Shan area is still largely debated (Jolivet et al., 2013), despite some efforts to reconstruct the sedimentary depositional environments (e.g. Hendrix et al., 1992; Li et al., 2004; Eberth et al., 2001; Vincent and Allen, 2001; Sha et al., 2011), the palaeo-topographic evolution (Dumitru et al., 2001; Jolivet et al., 2010; Yang et al., 2013; D. Liu et al., 2013; Yang et al., n.d. in press) and the palaeo-climate (e.g. Hendrix et al., 1992, 1994; Hendrix, 2000; Eberth et al., 2001; Li et al., 2004; Ashraf et al., 2010; Bian et al., 2010). In this paper, we provide new isotopic data on pedogenic carbonates (calcrete and nodules) and limestone beds in order to improve our understanding of the general evolution of the area from Late Jurassic to Early Palaeogene.

\section{Geological setting}

The Tian Shan is a large mountain belt extending in Central Asia through Kyrgyzstan, Kazakhstan and North-West China (Fig. 1a). This range is surrounded by several basins among which the Junggar Basin to the north and the Tarim Basin to the south (Fig. 1b). In the central part of the Tian Shan, several intramontane basins are preserved such as the Yili, Bayanbulak and Turfan basins (Fig. 1 and 2). The Tian Shan Range is limited by large crustal thrusts verging northward in the north and southward in the south towards the Junggar and Tarim Basins respectively (Fig. 1b). During the Palaeozoic, several accretion events gave rise to an important topography that was progressively eroded from Middle Triassic to Middle Jurassic (e.g. Dumitru et al., 2001; Li et al., 2004; Jolivet et al., 2010; 2013; Yang et al., 2013; S. Liu et al., 2013). The present-day topography formed later, mostly through the Cenozoic reactivation of Late Palaeozoic tectonic structures, driven by the far-field effects of the India-Asia collision event (e.g. Tapponnier and Molnar, 1979; Windley et al., 1990; Allen et al., 1991; Hendrix et al., 1994; Glorie et al., 2010; De Grave et al., 2011, 2013). Whereas the present-day topography is believed to have developed since Late Oligocene - Miocene (e.g. Charreau et al., 2005, 2009, 2012), uncertainties remain about the topographic evolution of the range during the Jurassic - Early Palaeogene period. For example, while low-thermochronology data suggest a long 
tectonic quiescence during most of the Mesozoic leading to very slow and constant exhumation within the range (Dumitru et al., 2001; Jolivet et al., 2010; 2013), Upper Jurassic alluvial fan deposits exposed in the foothills are interpreted as the consequence of a compressive reactivation of the range (Hendrix et al., 1992; Li et al., 2004). In this context, the present study on calcretes and nodules provides independent information on the palaeo-topographic evolution of the area.

\section{Field work and samples}

\subsection{Field description}

Throughout the area, we recognized several calcareous features (calcretes and nodules) at distinct stratigraphic levels (Fig. 2). Very few age data are available due to the lack of clear marine deposits, the scarcity of interbedded volcanic levels and the very limited available palynological and faunistic data (e.g. Wang and Gao, 2012; Yang et al., 2013). Nevertheless regional stratigraphic correlations can be made using available geological maps and the stratigraphic columns presented in published palynoflora and vertebrate studies (e.g. Eberth et al., 2001; Bian et al., 2010; Jiang et al., 2008; Heilbronn, 2014), as well as our own observations.

Below is a short description of the stratigraphy and the inferred associated depositional environments (Heilbronn, 2014). The present-day semi-arid climate of this region offers excellent outcrops preservation and exposure. In the northern foothills, from west to east (Fig. 1), the Wusu section exposes $1650 \mathrm{~m}$ of Middle Jurassic to Upper Cretaceous series, the Manas section exposes $8100 \mathrm{~m}$ of Triassic to Neogene series and the Qiu Er Gou section exposes $55 \mathrm{~m}$ of late Upper Cretaceous deposits. In the Bayanbulak intramontane basin (Fig. 1), $620 \mathrm{~m}$ of Jurassic to Neogene series are exposed, the stratigraphic continuity of which remains questionable. Finally, in the southern foothills, the Yaha section provides 2800 m of Jurassic to Neogene deposits.

The Mesozoic series of the Tian Shan area are constituted of continental deposits (Hendrix et al., 1992; Li et al., 2004; Jiang et al., 2008; Li and Peng, 2010). These series are mainly composed of stream and alluvial plain deposits (few decimetres- to a few metre-thick grey and red sandstone beds) alternating with floodplain or lake deposits (clays and siltstones). Thick conglomerates which deposited in an alluvial fan environment are exposed at the end of the Upper Jurassic and the Upper Cretaceous series (Fig. 2). 

Cretaceous and the late Upper Cretaceous to Palaeocene. The most continuous level of neo-formed carbonate is located in the later. This calcrete consists of a several metres thick indurated and white layer, parallel to the bedding and laterally continuous over tens of kilometres (Fig. 3a). The calcrete is commonly associated with conglomeratic beds (host rock), consisting in matrix-supported conglomerates with sub-angular to sub-rounded pebbles (Fig. 3b). Carbonate nodules are white, crumbly to highly indurated, spherical to elongated concretions of micritic carbonate (few centimetres in diameter), and either occur as disseminated bodies in red silty to sandy levels or form coalescent beds. Such a feature is classical for pedogenic carbonate (see Fig. $3 \mathrm{E}$ in Li et al., 2013). On several locations, one can observe a vertical transition from a zone enriched in nodules towards the massive calcrete layer (Fig. 3c); both features thus likely represent two stages of calcification, complete for calcrete, incipient for nodules. Processes controlling the formation of massive calcretes are still discussed and it is likely that both phreatic and pedogenic processes are involved (e.g. Wright, 2008 and references therein).

Moreover some limestone beds occur in the silty to sandy alternations of the late Middle Jurassic continental series of the Yaha section (Fig. 2) (e.g. Jiang et al., 2008). They are white to dark grey in colour, several centimetres- to several decimetres-thick and rather continuous laterally (Fig. 3d) and often show evidence of bioturbation (burrows). Middle Jurassic brackish water incursions have been inferred along the southern margin of the Junggar Basin (Chen and Zhang, 2000; Sha et al., 2011; Pan et al., 2013). We thus analysed those limestone beds in order to check their possible marine origin, even if they are interbedded with sediment series described as continental deposits (Hendrix et al., 1992; Sobel,1999; Jiang et al., 2008).

\subsection{Sampling strategy}

The recognition of nodules and calcrete layers in several places throughout the Tian Shan Range and their localization in the same stratigraphic levels (Upper Jurassic, Upper Cretaceous) offer a unique opportunity to specify the palaeo-topographic evolution of the area during the late Mesozoic. Every observed type of carbonated pedogenic feature has been sampled. Samples were first collected along a north-south transect across the Tian Shan, mostly focusing on the Manas, Bayanbulak and Yaha sections. For the Upper Cretaceous level, five to six samples have been collected from each section (Table 1; Fig. 2). When the calcrete and nodules were present together in a single site, both were sampled as they might have formed under distinct pedogenic conditions, 
even if some continuity between the two types of objects has been locally observed (Fig. 3c). For the Jurassic period, the sampling is not fully complete since calcification has not been observed in the Bayanbulak section and is only poorly developed in the Manas and Wusu sections.

On the northern foothills, six samples were also collected from the Qiu Er Gou section only $20 \mathrm{~km}$ east of the Manas section (Fig. 1). Calcification in these two close-by sites is located in the Upper Cretaceous series and likely developed under identical climatic and topographic conditions. They thus allow specifying the isotopic heterogeneities solely associated with the calcification processes. For example, evaporation can induce kinetic effects that modify the $\delta^{18} \mathrm{O}$ signature of pedogenic carbonates (Ufnar et al., 2008 and references therein).

Finally, several late Middle Jurassic limestone beds have been sampled on the Yaha section (Fig. 3d) both in order to confirm or infirm their suspected lacustrine origin using the isotopic tool, and to use their isotopic composition as a complementary proxy to palaeo-environmental reconstruction (e.g. Li et al., 2013).

\section{3.3 Sample description and preparation}

169 A total of 32 fist-sized samples have been collected (Fig. 4). Calcrete samples consist of 170 conglomerates in which the matrix has been cemented by neo-formed calcite (Fig. 4a). Figure 4a shows white calcite cement that precipitated around the pebbles. This cement has been sampled by scraping or micro-drilling and reduced to powder for isotopic analysis. Since the conglomerates contain some detrital fragments of carbonate rocks, special care was taken to avoid contamination of the sampled powder by pebble-derived carbonate. In one sample of the Manas section (sample MC 11-3; Table 1), three types of neo-formed carbonates were observed and sampled: calcitic cement (fraction A), a few millimeters wide veinlets (fraction B) and millimetric geodic calcite grains (fraction C).

Nodule samples consist of nearly pure neo-formed calcite, sometimes easily extracted from their sandy to silty host rock (Fig. 4b). These nodules were crushed and neo-formed calcite was separated by hand-picking from remaining small detrital grains. For both the calcrete and nodule samples, the separated calcite was then crushed in a boron carbide mortar before analysis. 
182 Limestone samples sometimes contain some detrital materials, but no pebble was observed.

\section{Analytical techniques}

\section{Results}

In Table 1, for the Qiu Er Gou section where calcrete and nodules have been collected in nearby horizons, there is no significant isotopic difference between the two facies. These two components are thus not distinguished in Figure 5a.

The analytical data are rather clustered (our data shown in black and grey on Fig. 5), with some points lying outside of the main field. The data for calcrete and nodules are shown in Figure 5a and those for limestones in Fig. $5 \mathrm{~b}$. On the Manas section, the lowest $\delta^{18} \mathrm{O}$ value $(19.2 \% \mathrm{o})$ was measured for the geodic calcite (sample MC 11-3A, see Fig. 5a), suggesting that this calcite developed under physicochemical conditions distinctly different from the ones prevailing during the main calcification event. On the same section, the Palaeogene nodule MC 11-SED-6 (see Fig. 5a) is somewhat different from the others, displaying lower $\delta^{18} \mathrm{O}(20.4 \%)$ and $\delta^{13} \mathrm{C}(-6.1 \%)$ values. On the Yaha section, the two Jurassic nodules (YA 12-SED-39 and 41, see Fig. 5a) display extreme $\delta^{13} \mathrm{C}$ values, respectively of -7.6 and $-2.0 \%$. Similarly, the Lower Cretaceous nodule (YA 12-CHIM-1, see Fig. 5a) is also distinguishable from the Upper Cretaceous - Lower Palaeogene calcrete by higher $\delta^{18} \mathrm{O}(24.6 \% \mathrm{o})$ and $\delta^{13} \mathrm{C}(-2.98 \%)$ values. On the Yaha section, while the calcrete displays homogeneous isotopic 
compositions, the nodules show wider isotopic ranges and only the Palaeogene nodule YA 12-SED19A (see Fig. 5a) shows a composition identical to that of the Yaha calcrete.

However, in spite of these differences, the Upper Cretaceous - Lower Palaeogene calcrete and nodules of the Tian Shan display rather homogeneous oxygen and carbon isotope compositions, irrespective of the sampling site. Fluctuations are small in comparison to the range of possible values.

Indeed, most of the Upper Cretaceous - Lower Palaeogene calcrete and nodule $\delta^{18} \mathrm{O}$ values are between 21 and 25\% (SMOW), while most of the $\delta^{13} \mathrm{C}$ values are between -4 and $-6 \%$ (PDB) (Fig. 5a). On the other hand, the Tian Shan calcrete and nodules differ overall from other calcretes in China (Early Cretaceous in age; Li et al., 2013) by lower $\delta^{13} \mathrm{C}$ values and more homogeneous compositions.

Finally, the Middle Jurassic limestone beds from the Yaha section have highly variable oxygen and carbon isotope composition: $\delta^{18} \mathrm{O}$ values are between 18 and 23\% (SMOW) and $\delta^{13} \mathrm{C}$ values are between -3.5 and $+3.1 \%$ (PDB), well outside the field of unaltered marine limestones (Fig. $5 \mathrm{~b}$ ). When compared to the lacustrine limestones analysed by Li et al. (2013), the values obtained in the Yaha limestones fall within the field of the SE China and NW China data. We thus interpret those limestones as lacustrine deposits.

\section{Discussion}

The stable isotope dataset presented here allow us discussing several characteristics of the palaeo-environmental evolution of the Chinese Tian Shan. Indeed, the isotope compositions of the pedogenic carbonates formed in equilibrium with soil or ground water are believed to record a significant part of the original signature of the water, which is itself influenced by several geographical and morphological parameters: continentality, latitude and altitude. Consequently, besides climatic evolution, any topographic changes across space or through time will induce an evolution in the isotopic record.

The Yaha section provides a record of calcification conditions in both the Late Jurassic and the Late Cretaceous - Early Palaeogene times, which helps discussing the evolution of the southern foothills during the Late Mesozoic. The pre-requisite of such analyses is that calcification developed soon after sediment deposition. Although there is no indication for this in the Tian Shan, the nodules were often found in close association with the calcrete (Fig. 3c) and were thus very likely developed 
241 close to the surface. Only the small geodic calcite with an oxygen isotope composition distinct from

1

2

243

5244

7245

246

247 the whole nodule and calcrete population (sample MC 11-3A) obviously developed in association with some diagenetic event, after the main calcification phase. This shows that the diagenetic circulations that occurred in the series induced isotopic deviation strong enough to be recorded in our data. To a first order, excluding these data (see sample MC 11-3A), it is thus reasonable to discuss the Late Cretaceous - Early Palaeogene palaeo-climatic and palaeo-topographic characteristics, using calcretes and nodules that developed at this stratigraphic level. Finally, some aspects linked to the process of calcification itself can be discussed.

\subsection{Isotopic variability within a calcification site}

As previously mentioned, numerous processes can influence the isotopic values of pedogenic carbonates (e.g. Ufnar et al., 2008; Charreau et al., 2012; Li et al., 2013), independently of the initial composition of the meteoric water. Some effects are related to the hydrological conditions (evaporation, respiration, seasonality) and influence the oxygen isotopic record. Others are linked to the nature of the palaeo-flora and the relative amount of organic carbon over inorganic carbon hosted in limestones which are mostly of marine origin. It is far beyond the scope of this study to discuss the impact of each of these processes on the isotopic composition of the nodules and calcrete that we measured (the reader is invited to refer to the exhaustive discussion developed in Ufnar et al., 2008; Charreau et al., 2012; Li et al., 2013). Instead, we sampled two neighbouring sites (the Manas and Qiu Er Gou sections) in the northern foothills in order to specify the range of isotopic heterogeneity associated with the calcification processes in our study area. The range of values of the Qiu samples are 21.4 to $24.6 \%$ o $\left(\delta^{18} \mathrm{O}\right)$ and -4.29 to $-6.14 \%$ o $\left(\delta^{13} \mathrm{C}\right)$, while the range of the Manas samples are 19.2 to $25.3 \%$ o $\left(\delta^{18} \mathrm{O}\right)$ and -3.75 to $-6.08 \%$ o $\left(\delta^{13} \mathrm{C}\right)$. We consider these ranges as quite comparable.

Each site displays a similar range in $\delta^{18} \mathrm{O}$ values for the Upper Cretaceous - Lower Palaeogene calcrete and nodules $\left(\delta^{18} \mathrm{O}\right.$ between 22 and 25.3\% for the Manas site, between 21.4 and $24.6 \%$ o for the Qiu Er Gou site; Table 1). The $\delta^{13} \mathrm{C}$ values are also comparable $\left(\delta^{13} \mathrm{C}\right.$ between -3.7 and $-4.9 \%$ for the Manas site, between -4.3 and $-6.0 \%$ for the Qiu Er Gou site). The carbonation processes acting at both sites were thus nearly identical, inducing comparable isotopic heterogeneity.

Also, some neo-formed carbonates display specific isotopic compositions in relation to original textural characteristics. The most obvious one is the geodic calcite that developed in the calcrete of the Manas section (MC $11-3 A$ ). This calcite has a $\delta^{18} \mathrm{O}$ of $19.2 \%$ which is lower than that one of its calcrete host (22.2\%o). Two main factors can lower the $\delta^{18} \mathrm{O}$ value of carbonate. Firstly, the 
$273 \quad \delta^{18} \mathrm{O}$ value of the fluid may have been $3 \%$ lower when the geode developed than when the calcrete formed. Secondly, the isotopic fractionation is inversely correlated with temperature. Assuming a constant $\delta^{18} \mathrm{O}$ value of the water from which precipitation occurred, a higher temperature of precipitation during the formation of the geode could result in a lower $\delta^{18} \mathrm{O}$ value of the calcite. We favor this second hypothesis for two reasons. Firstly, lowering the $\delta^{18} \mathrm{O}$ value of the original meteoric water would imply a drastic change in palaeo-climate or palaeo-environmental conditions between the calcrete stage and the geodic stage, a set of conditions that should be recorded by other proxies like the sedimentological record itself and in neighbor areas of Central Asia, which is not the case (e.g. Li et al., 2004). Secondly, a decrease of $3 \%$ of the $\delta^{18} \mathrm{O}$ value of calcite corresponds to an increase of the temperature of calcite precipitation of about $12-15^{\circ} \mathrm{C}$ : if calcrete precipitated at $20^{\circ} \mathrm{C}$, which corresponds reasonably to pedogenic carbonation conditions, the geode may have precipitated at about $32-35^{\circ} \mathrm{C}$. This temperature increase may correspond to burial of the series of a few hundreds of metres within a normal geothermal gradient, a burial that actually occurred in the area during the Cenozoic. Therefore, the geodic calcite developed under late diagenetic conditions rather than under early pedogenic ones.

\subsection{Temporal evolution on the southern foothills (Yaha section)}

Along the Yaha section, the calcification features formed merely during the Late Jurassic and the Late Cretaceous - Early Palaeogene. These pedogenic carbonates suggest that both periods were characterized by a similar semi-arid climate (e.g. Hendrix et al., 1992; Li et al., 2004; Sun and Wang, 2005). Moreover, the oxygen isotope composition of the neo-formed carbonates is comparable: from 21.2 to $22.6 \%$ o for the Jurassic, and from 21.6 to $23.4 \%$ o for the Early Palaeogene, which is again consistent with similar climatic conditions. In fact, the Late Cretaceous sample YA-12-CHIM-1 displays a $\delta^{18} \mathrm{O}$ value $(24.6 \%$ ) slightly above the other Yaha samples.As we have only one sample for this intermediate stratigraphic level, we can hardly consider this single value as representative of a regional palaeo-environmental event. It remains that the homogeneity of the stable isotope compositions of the calcification features studied here may indicate that our samples underwent comparable in-situ processes such as evaporation. This homogeneity also suggests that the composition of the rainwater, and by inference also the fundamental parameters evaporation, continentality, latitude, and altitude were likely comparable in the Yaha region for the Late Jurassic and Early Palaeogene periods. In other words, based on our isotopic data no major palaeo- 
geographic changes occurred during this period in the Yaha region (confirms earlier data published by Li et al., 2004), i.e. no significant topographic variations occurred either by relief building or destruction. Furthermore, the transgression of the Paratethys Sea from the West into the Tarim Basin during the Late Cretaceous (e.g. Sobel, 1999) had no influence on the conditions of development of pedogenic carbonates in the Yaha section.

In the Yaha region, the isotopic compositions of the Middle Jurassic limestones are different from those of marine limestones of the same age elsewhere in the world (Veizer et al., 1999) (Fig. 5b). It could be argued that these limestones were originally marine and that subsequent diagenesis affected their primary compositions, as known for many carbonate platforms (e.g. Brigaud et al., 2009). However, the fact that $\delta^{13} \mathrm{C}$ of the limestones is highly variable and that the $\delta^{13} \mathrm{C}$ values are not correlated with the $\delta^{18} \mathrm{O}$ values, does not plead for such a diagenetic modification of marine limestones. Indeed, the $\delta^{18} \mathrm{O}$ values of the limestones ranging between 18 and $23 \%$, the large $\delta^{13} \mathrm{C}$ variation with both positive and negative values and the lack of correlation between the oxygen and carbon signatures are common features of lacustrine carbonates (e.g. Li et al., 2013 and references therein). These authors provided a very detailed discussion on the use of these isotopic signatures in terms of palaeo-environmental reconstructions. In the present work, it would be hazardous to develop such a discussion because of the rather small number of isotopic data. Our inference that the limestone beds are lacustrine is consistent with the silty to sandy continental nature of the series in which they are inter-bedded (see field description above and in Hendrix et al., 1992; Sobel, 1999; Jiang et al., 2008; Heilbronn, 2014).

\subsection{Palaeo-topography during the Late Cretaceous - Early Palaeogene period}

We have analysed calcification features in three Upper Cretaceous - Lower Palaeogene series in the north, the south and within the Tian Shan Range. Currently, there are two first order differences between the northern and southern sides of the range (Charreau et al., 2012): 1) the cumulative meteoric precipitation rate is much higher on the northern side; i.e., between 100 and $250 \mathrm{~mm} /$ year in the southern Junggar Basin than on the southern side of the Tian Shan; i.e., less than $40 \mathrm{~mm} /$ year in the Tarim Basin, and 2) the mean $\delta^{18} \mathrm{O}$ value of meteoric water is lower than $-8 \%$ on the northern side and higher than this value on the southern side. If a significant palaeo-topography 
existed during the Late Cretaceous - Early Palaeogene period, such an isotopic gradient in meteoric water compositions likely existed and should have been recorded in pedogenic carbonates.

From the lithological point of view, our field observation showed that calcrete features developed mainly in conglomerates, i.e. on rocks with comparable porosity and permeability properties. Also, a semi-arid climate prevailed over the whole study area in order to develop pedogenic carbonates (e.g. Hendrix et al., 1992). It is then reasonable to think that the prominent variable that could have been recorded by the carbonates developed in the Upper Cretaceous Lower Palaeogene series, is the initial isotopic composition of the meteoric water, a property that depends primarily on the origin of atmospheric masses (e.g. Charreau et al., 2012). In Table 1 and Figure 5, there is no significant isotopic difference between the Upper Cretaceous - Lower Palaeogene pedogenic carbonates of the northern, central and southern parts of the present-day Tian Shan Range. The interpretation that immediately comes out is that the meteoric waters were identical in the three regions.

The easier way to reach identical values is to consider that these meteoric waters originated from the same oceanic reservoir and underwent the same atmospheric evolution. The Paratethys sea in the West-Tarim Basin (e.g. Dercourt et al., 1993; Mao and Norris, 1988) could be a possible source of these meteoritic waters. Regardless of the marine source of meteoric waters, there is no isotopic evidence for the existence of any orographic barrier between the studied sections at the time of calcification. If the latter rapidly followed deposition, there was no significant relief in that area at the Cretaceous - Palaeogene boundary.

\section{Conclusion}

Pedogenic carbonates (calcrete and nodules) and limestone beds have been identified and analysed for $\delta^{18} \mathrm{O}$ and $\delta^{13} \mathrm{C}$ on two main stratigraphic levels of the Tian Shan Mesozoic-Cenozoic series (Late Jurassic and Late Cretaceous - Early Palaeogene). The limestone beds are restricted to the Middle Jurassic series of the southern foothills and are probably of lacustrine origin. The oxygen and carbon isotope compositions of the pedogenic carbonates are homogeneous in both the southern and northern foothills of the Tian Shan Range, as well as in the intramontane Bayanbulak Basin. Palaeo-environmental conditions of pedogenic carbonates development were thus identical on a regional scale during the Late Cretaceous - Early Palaeogene period. No significant palaeo-relief 
existed by that time in the area, implying that the actual Tian Shan topography mostly results from the Cenozoic reactivation event.

\section{Acknowledgements}

This work was supported by the DARIUS Program, the French CNRS-INSU Syster Program, and the French-Chinese EGIDE Cai Yuanpei Program. The work of L. Barrier for this paper is the IPGP contribution \#3442. We are thankful to the anonymous reviewers of this paper for their constructive comments and remarks.

\section{References}

Allen, M.B., Windley, B.F., Zhang Chi, Zhao Zhong-yan, Wang Guang-Rei, 1991. Basin evolution within and adjacent to the Tien Shan Range, NW China. J. Geol. Soc. Lond. 148, 369-378.

Alonso-Zarza, A.M., 2003. Palaeoenvironmental significance of palustrine carbonates and calcretes in the geological record. Earth-Sci. Rev. 60, 261-298.

Ashraf, A.R., Sun, Y., Sun, G., Uhl, D., Mosbrugger, V., Li, J., Herrmann, M., 2010. Triassic and Jurassic palaeoclimate development in the Junggar Basin, Xinjiang, Northwest China - a review and additional lithological data. Palaeobiodiversity Palaeoenvironments 90, 187-201.

Bian, W., Hornung, J., Liu, Z., Wang, P., Hinderer, M., 2010. Sedimentary and palaeoenvironmental evolution of the Junggar Basin, Xinjiang, Northwest China. Palaeobiodiversity Palaeoenvironments $90,175-186$.

Brigaud, B., Durlet, C., Deconinck, J.-F., Vincent, B., Thierry, J., Trouiller, A., 2009. The origin and timing of multiphase cementation in carbonates: Impact of regional scale geodynamic events on the Middle Jurassic Limestones diagenesis (Paris Basin, France). Sediment. Geol. 222, 161-180.

Charreau, J., Chen, Y., Gilder, S., Barrier, L., Dominguez, S., Augier, R., Sen, S., Avouac, J.-P., Gallaud, A., Graveleau, F., Wang, Q., 2009. Neogene uplift of the Tian Shan Mountains observed in the magnetic record of the Jingou River section (northwest China). Tectonics 28, TC2008.

Charreau, J., Chen, Y., Gilder, S., Dominguez, S., Avouac, J., Sen, S., Sun, D., Li, Y., Wang, W., 2005. Magnetostratigraphy and rock magnetism of the Neogene Kuitun He section (northwest China): implications for Late Cenozoic uplift of the Tianshan mountains. Earth Planet. Sci. Lett. 230, 177-192. 
Charreau, J., Kent-Corson, M.L., Barrier, L., Augier, R., Ritts, B.D., Chen, Y., France-Lannord, C., Guilmette, C., 2012. A high-resolution stable isotopic record from the Junggar Basin (NW China): Implications for the paleotopographic evolution of the Tianshan Mountains. Earth Planet. Sci. Lett. 341, 158-169.

Chen, J.-H., Zhang, Y.-J., 2000. Marine bivalves found in Lower Jurassic of continental Junggar Basin of west China. Xinjiang Geol. 18, 28-31.

De Grave J., Glorie, S., Buslov, M.M., Izmer, A., Fournier-Carrie, A., Batalev, V.Y., Vanhaecke, F., Elburg, M., Van den haute, P., 2011. The thermo-tectonic history of the Song-Kul plateau, Kyrgyz Tien Shan: Constraints by apatite and titanite thermochronometry and zircon U/Pb dating. Gondwana Research 20, 745-763.

De Grave J., Glorie, S., Buslov, M.M., Stockli, D.F., McWilliams, M.O., Batalev, V.Y., Van den haute, P., 2013. Thermo-tectonic history of the Issyk-Kul basement (Kyrgyz Northern Tien Shan, Central Asia). Gondwana Research 23, 998-1020.

Dercourt, J., Ricou, L.-E., Vrielynck, B., 1993. Atlas Tethys, Paleoenvironmental Maps: Explanatory Notes. Gauthier-Villars.

Dumitru, T.A., Zhou, D., Chang, E.Z., Graham, S.A., Hendrix, M.S., Sobel, E.R., Carroll, A.R., 2001. Uplift, exhumation, and deformation in the Chinese Tian Shan. Geol. Soc. Am. Mem. 194, 71 -99.

Eberth, D.A., Brinkman, D.B., Chen, P.-J., Yuan, F.-T., Wu, S.-Z., Li, G., Cheng, X.-S., 2001. Sequence stratigraphy, paleoclimate patterns, and vertebrate fossil preservation in Jurassic-Cretaceous strata of the Junggar Basin, Xinjiang Autonomous Region, People's Republic of China. Can. J. Earth Sci. 38, 1627-1644.

Garzione, C.N., Dettman, D.L., Quade, J., DeCelles, P.G., Butler, R.F., 2000. High times on the Tibetan Plateau: Paleoelevation of the Thakkhola graben, Nepal. Geology 28, 339-342.

Glorie, S., De Grave, J., Buslov, M.M., Elburg, M.A., Stockli, D.F., Gerdes, A., 2010. Multi-method chronometric constraints on the evolution of the Northern Kyrgyz Tien Shan granitoids (Central Asian Orogenic Belt): From emplacement to exhumation. Journal of Asian Earth Sciences 38, 131-146.

Hasiotis, S.T., Kraus, M.J., Demko, T.M., 2007. Climatic controls on continental trace fossils. Trace Foss. Concepts Probl. Prospects Elsevier Amst. 172-195.

Heilbronn, G., 2014. Palaeogeographic and palaeotopographic evolution of the Chinese Tian Shan during the Mesozoic. Thèse - Université de Rennes 1, 267 p.

Hendrix, M.S., 2000. Evolution of Mesozoic Sandstone Compositions, Southern Junggar, Northern Tarim, and Western Turpan Basins, Northwest China: A Detrital Record of the Ancestral Tian Shan. J. Sediment. Res. 70, 520-532.

Hendrix, M.S., Dumitru, T.A., Graham, S.A., 1994. Late Oligocene-early Miocene unroofing in the Chinese Tian Shan: An early effect of the India-Asia collision. Geology 22, 487-490. 
Hendrix, M.S., Graham, S.A., Carroll, A.R., Sobel, E.R., McKnight, C.L., Schulein, B.J., Wang, Z., 1992. Sedimentary record and climatic implications of recurrent deformation in the Tian Shan: Evidence from Mesozoic strata of the north Tarim, south Junggar, and Turpan basins, northwest China. Geol. Soc. Am. Bull. 104, $53-79$.

Jiang, D.-X., Wang, Y.-D., Robbins, E.I., Wei, J., Tian, N., 2008. Mesozoic non-marine petroleum source rocks determined by palynomorphs in the Tarim Basin, Xinjiang, northwestern China. Geol. Mag. 145, 868-885.

439 Jolivet, M., Dominguez, S., Charreau, J., Chen, Y., Li, Y., Wang, Q., 2010. Mesozoic and Cenozoic 440 tectonic history of the central Chinese Tian Shan: Reactivated tectonic structures and active 441 deformation. Tectonics 29, TC6019.

442 Jolivet, M., Heilbronn, G., Robin, C., Barrier, L., Bourquin, S., Guo, Zh., Jia, Y., Guerit, L., Yang, W., Fu 443 B., 2013. Reconstructing the Late Palaeozoic - Mesozoic topographic evolution of the Chinese Tian 444 Shan: available data and remaining uncertainties. Advances in Geosciences 37, 7-18.

Jolivet, M., Barrier, L., Dominguez, S., Guerit, L., Heilbronn, G., Fu, B., 2014. Unbalanced sediment budgets in the catchment - alluvial fan system of the Kuitun River (northern Tian Shan, China): Implications for mass-balance estimates and erosion rates in mountain ranges. Geomorphology 214, 168-182.

Li, X., Xu, W., Liu, W., Zhou, Y., Wang, Y., Sun, Y., Liu, L., 2013. Climatic and environmental indications of carbon and oxygen isotopes from the Lower Cretaceous calcrete and lacustrine carbonates in Southeast and Northwest China. Palaeogeogr. Palaeoclimatol. Palaeoecol. 385, 171-189.

Li, Z., Peng, S., 2010. Detrital zircon geochronology and its provenance implications: responses to Jurassic through Neogene basin-range interactions along northern margin of the Tarim Basin, Northwest China. Basin Res. 22, 126-138.

Li, Z., Song, W., Peng, S., Wang, D., Zhang, Z., 2004. Mesozoic-Cenozoic tectonic relationships between the Kuqa subbasin and Tian Shan, northwest China: constraints from depositional records. Sediment. Geol. 172, 223-249.

Liu, D., Jolivet, M., Yang, W., Zhang, Z., Cheng, F., Zhu, B., Guo, Z., 2013. Latest Paleozoic-Early Mesozoic basin-range interactions in South Tian Shan (northwest China) and their tectonic significance: Constraints from detrital zircon U-Pb ages. Tectonophysics 599, 197-213.

Liu, S., Su, S., Zhang, G., 2013. Early Mesozoic basin development in North China: Indications of cratonic deformation. J. Asian Earth Sci. 62, 221-236.

Mao, S., Norris, G., 1988. Late Cretaceous-early Tertiary dinoflagellates and acritarchs from the Kashi area, Tarim Basin, Xinjiang Province, China. Life Science Contributions, 150 Royal Ontario Museum, , $93 p$.

Pan, Y., Sha, J., Wang, Y., Zhang, X., Yao, X., Peng, B., Rao, X., 2013. The brackish-water bivalve Waagenoperna from the Lower Jurassic Badaowan Formation of the Junggar Basin and its palaeoenvironmental and palaeogeographic significance. Geosci. Front. 4, 95-103. 
Pustovoytov, K.E., 2002. Pedogenic carbonate cutans on clasts in soils as a record of history of grassland ecosystems. Palaeogeogr. Palaeoclimatol. Palaeoecol. 177, 199-214.

Retallack, G.J., 1997. Colour guide to paleosols. John Wiley, Chichester [England]; New York, 175 p.

Sha, J., Vajda, V., Pan, Y., Larsson, L., Yao, X., Zhang, X., Wang, Y., Cheng, X., Jiang, B., Deng, S., Chen, S., Peng, B., 2011. Stratigraphy of the Triassic-Jurassic Boundary Successions of the Southern Margin of the Junggar Basin, Northwestern China. Acta Geol. Sin. - Engl. Ed. 85, 421-436.

Sobel, E.R., 1999. Basin analysis of the Jurassic-Lower Cretaceous southwest Tarim basin, northwest China. Geol. Soc. Am. Bull. 111, 709-724.

Sun, X., Wang, P., 2005. How old is the Asian monsoon system?-Palaeobotanical records from China. Palaeogeogr. Palaeoclimatol. Palaeoecol. 222, 181-222.

Tapponnier, P., Molnar, P., 1979. Active faulting and Cenozoic tectonics of the Tien Shan, Mongolia, and Baykal regions. J. Geophys. Res. 84, 3425-3459.

Ufnar, D.F., Gröcke, D.R., Beddows, P.A., 2008. Assessing pedogenic calcite stable-isotope values: Can positive linear covariant trends be used to quantify palaeo-evaporation rates? Chem. Geol. 256, 4651.

Veizer, J., Ala, D., Azmy, K., Bruckschen, P., Buhl, D., Bruhn, F., Carden, G.A.F., Diener, A., Ebneth, S., Godderis, Y., Jasper, T., Korte, C., Pawellek, F., Podlaha, O.G., Strauss, H., 1999. 87Sr/86Sr, $113 \mathrm{C}$ and $\delta 180$ evolution of Phanerozoic seawater. Chem. Geol. 161, 59-88.

Vincent, S.J., Allen, M.B., 2001. Sedimentary record of Mesozoic intracontinental deformation in the eastern Junggar Basin, northwest China: Response to orogeny at the Asian margin. Geol. Soc. Am. Mem. 194, $341-360$.

Wang, S.-E., Gao, L.-Z., 2012. SHRIMP U-Pb dating of zircons from tuff of Jurassic Qigu Formation in Junggar Basin, Xinjiang. Geol. Bull. China 31, 503-509.

Windley, B.F., Allen, M.B., Zhang, C., Zhao, Z.-Y., Wang, G.-R., 1990. Paleozoic accretion and Cenozoic redeformation of the Chinese Tien Shan Range, central Asia. Geology 18, 128-131.

Wright, V.P., 2008. Calcrete, in: Nash, D.J., McLaren, S.J. (Eds.), Geochemical Sediments and Landscapes. Blackwell Publishing Ltd, pp. 10-45.

Wright, V.P., Tucker, M.E., 1991. Calcretes. Blackwell Scientific Publications, Oxford, 1-22.

Yang, W., Jolivet, M., Dupont-Nivet, G., Guo, Z., 2014. Mesozoic-Cenozoic tectonic evolution of southwestern Tian Shan: evidence from detrital zircon $\mathrm{U} / \mathrm{Pb}$ and apatite fission track ages of the Ulugqat area, Northwest China. Gondwana Res. 26, 986-1008.

Yang, W., Jolivet, M., Dupont-Nivet, G., Guo, Z., Zhang, Z., Wu, C., 2013. Source to sink relations between the Tian Shan and Junggar Basin (northwest China) from Late Palaeozoic to Quaternary: evidence from detrital U-Pb zircon geochronology. Basin Res. 25, 219-240. 


\section{Table caption}

Table 1- Oxygen and carbon isotope composition of the pedogenic and lacustrine carbonates from the Tian Shan Range.

\section{Figure caption}

Fig. 1- a) Schematic tectonic map of Asia and location of the Tian Shan Range in Central Asia. b) Map of the Tian Shan area (DEM, G-TOPO-30, Mercator projection) showing the five sampling sites: the Wusu, Manas and Qiu Er Gou sections on the northern foothills, the Bayanbulak section in the Bayanbulak intramontane basin, and the Yaha section on the southern foothills of the range. Section location and GPS coordinates are given in Table 1.

Fig. 2- Synthetic figure showing (top) the present-day topographic profile through the Tian Shan Range, together with the five sampling sites (black dots; W. = Wusu; M. = Manas; Q. = Qiu Er Gou; B. $=$ Bayanbulak; Y. = Yaha). (left) General lithological column $(\mathrm{C}=$ Clay, $\mathrm{s}=\mathrm{Silt}, \mathrm{Sf}=$ Fine sand, $\mathrm{Sm}=$ Medium sand, $\mathrm{Sc}=$ Coarse sand, $\mathrm{g}=$ Gravel, $\mathrm{P}=$ Pebble, $\mathrm{B}=$ Boulder) derived from our field observations of the Middle Jurassic to Palaeocene series from the Yaha section (southern foothills). This column shows the general trends and types of Mesozoic deposits around the Tian Shan Range and is consistent with the work of Hendrix et al. (1992). The correspondence between lithological limits and stratigraphic ages relies on the available geological maps, previous studies (Hendrix et al., 1992) and our field work (J1 = Early Jurassic; J2 = Middle Jurassic; J3 = Late Jurassic; K1 = Early Cretaceous; K2 = Late Cretaceous; $\mathrm{P}=$ Palaeocene). (right) Type and stratigraphic position of the neoformed carbonates.

Fig. 3- Outcrop views. a) Landscape view of the sampled 8 metre-thick massive calcrete, which runs over tens of kilometres laterally (Late Cretaceous - Early Palaeocene, top of the Manas Section). b) Detailled view of the massive conglomeratic calcrete (hammer for scale). The boundaries of the carbonate body correspond to lithological limits between sandy layers and gravel-rich layers. c) Transition from nodule-rich layers into a massive calcrete (Late Cretaceous - Early Palaeocene, Yaha 
533 Section; hammer for scale). d) Decimetric grey to white limestone layers. These layers are not easily 1

Fig. 4- Examples of studied samples. a) Conglomeratic massive calcrete (sample MC 11 4; Late Cretaceous - Early Palaeocene; Manas section). b) Centrimetre-sized calcareous nodules (sample B 53811 SED 1; Early Palaeocene; Bayanbulak section). c) Limestone, locally with shales or terrigenous input (sample YA 12 SED 1; Middle Jurassic; Yaha section).

541 Fig. 5- $\delta^{13} \mathrm{C}$ (PDB) vs. $\delta^{18} \mathrm{O}$ (SMOW) diagram of the pedogenic carbonates (a) and the limestones (b) of 542 the Tian Shan Range. The isotopic compositions of Lower Cretaceous pedogenic carbonates and 543 limestones from China are shown for comparison (data from Li et al., 2013). The field of Jurassic 544 marine limestones of the world is indicated in grey (Veizer et al., 1999). 


\begin{tabular}{|c|c|c|c|c|c|c|}
\hline \multirow[b]{2}{*}{ Sample } & \multirow[b]{2}{*}{ Type } & \multirow[b]{2}{*}{ Formation } & \multicolumn{2}{|c|}{ Coordinates } & \multicolumn{2}{|c|}{ Calcite } \\
\hline & & & Latitude & Longitude & $\delta^{18} \mathrm{O}$ & $\delta^{13} \mathrm{C}$ \\
\hline \multicolumn{7}{|l|}{ WUSU } \\
\hline WE 12 SED 1 & Calcar. nodules & Jurassic (J3) & $44^{\circ} 8 ' 20,90^{\prime \prime} \mathrm{N}$ & $84^{\circ} 30^{\prime} 19,70^{\prime \prime} \mathrm{E}$ & 21.2 & -4.96 \\
\hline \multicolumn{7}{|l|}{ MANAS } \\
\hline MC 11 SED 6 & Calcar. nodules & Palaeogene & $43^{\circ} 57^{\prime} 55,08^{\prime \prime N}$ & $85^{\circ} 48^{\prime} 28,08^{\prime \prime E}$ & 20.4 & -6.08 \\
\hline MC 115 & Calcrete & Cret./Palaeogene & idem & & 25.3 & -3.75 \\
\hline MC 114 & Calcrete & Cret./Palaeogene & idem & & 23.7 & -4.22 \\
\hline MC $113 C$ & Calcrete (matrix) & Cret./Palaeogene & idem & & 22.2 & -4.05 \\
\hline MC $113 B$ & Calcrete (vein) & Cret./Palaeogene & idem & & 22.1 & -4.87 \\
\hline MC $113 A$ & Calcrete (geode) & Cret./Palaeogene & idem & & 19.2 & -4.73 \\
\hline MC 112 & Calcrete & Cret./Palaeogene & $43^{\circ} 57^{\prime} 42,72^{\prime \prime} \mathrm{N}$ & $85^{\circ} 48^{\prime} 27,60^{\prime \prime} \mathrm{E}$ & 22.0 & -4.67 \\
\hline \multicolumn{7}{|l|}{ QIU ER GOU } \\
\hline HU 12-SED 12 & Calcar. nodules & Cret./Palaeogene & $43^{\circ} 52^{\prime} 3,00^{\prime \prime} \mathrm{N}$ & $86^{\circ} 23^{\prime} 32,30^{\prime \prime} \mathrm{E}$ & 21.4 & -5.19 \\
\hline HU 12-SED 11 & Calcar. nodules & Cret./Palaeogene & & & 23.3 & -6.02 \\
\hline HU 12-SED 10 & Calcrete & Cret./Palaeogene & & & 24.6 & -4.29 \\
\hline HU 12-SED 9 & Calcrete & Cret./Palaeogene & & & 23.0 & -4.99 \\
\hline HU 12-SED 8 & Calcar. nodules & Cret./Palaeogene & & & 22.8 & -5.33 \\
\hline HU 12-SED 7 & Calcrete & Cret./Palaeogene & $43^{\circ} 52^{\prime} 2,40^{\prime \prime} \mathrm{N}$ & $86^{\circ} 23^{\prime} 29,50^{\prime \prime} \mathrm{E}$ & 22.7 & -6.14 \\
\hline \multicolumn{7}{|l|}{ BAYANBULAK } \\
\hline B 11 SED 1 & Calcar. nodules & Palaeogene? & $43^{\circ} 4^{\prime} 23,52^{\prime \prime} \mathrm{N}$ & $84^{\circ} 17^{\prime} 6,66^{\prime \prime} \mathrm{E}$ & 22.3 & -4.65 \\
\hline B 11 SED 06 & Calcrete & Cret./Palaeogene? & idem & & 23.1 & -5.31 \\
\hline B 11 SED 02 & Calcrete & Cret./Palaeogene? & idem & & 23.0 & -5.79 \\
\hline B 11 SED 05 & Calcrete & Cret./Palaeogene? & idem & & 24.3 & -5.32 \\
\hline B 11 SED 04 & Calcrete & Cret./Palaeogene? & $43^{\circ} 4^{\prime} 21,96^{\prime \prime} \mathrm{N}$ & $84^{\circ} 17^{\prime} 5,52^{\prime \prime} \mathrm{E}$ & 23.0 & -5.53 \\
\hline \multicolumn{7}{|l|}{ YAHA } \\
\hline YA 12 SED 19 A & Calcar. nodules & Palaeogene & $42^{\circ} 4^{\prime} 52,32^{\prime \prime} \mathrm{N}$ & $83^{\circ} 15^{\prime} 48,20^{\prime \prime} \mathrm{E}$ & 23.4 & -4.10 \\
\hline YA 12 SED 18 & Calcrete & Cret./Palaeogene & $42^{\circ} 4^{\prime} 56,30^{\prime \prime} \mathrm{N}$ & $83^{\circ} 15^{\prime} 48,20^{\prime \prime} \mathrm{E}$ & 22.7 & -4.75 \\
\hline YA 12 SED 17 & Calcrete & Cret./Palaeogene & $42^{\circ} 4^{\prime} 57,15^{\prime \prime} \mathrm{N}$ & $83^{\circ} 15^{\prime} 48,61^{\prime \prime E}$ & 22.7 & -4.95 \\
\hline YA 12 SED 13 & Calcrete & Cret./Palaeogene & $42^{\circ} 4^{\prime} 56,84^{\prime \prime} \mathrm{N}$ & $83^{\circ} 15^{\prime} 50,13^{\prime \prime E}$ & 21.6 & -4.13 \\
\hline YA 12 SED 16 & Calcrete & Cret./Palaeogene & $42^{\circ} 4^{\prime} 57,32^{\prime \prime} \mathrm{N}$ & $83^{\circ} 15^{\prime} 50,13^{\prime \prime E}$ & 21.7 & -3.86 \\
\hline YA 12 CHIM 1 & Calcar. nodules & Cretaceous (K1) & $42^{\circ} 5^{\prime} 47,80^{\prime \prime} \mathrm{N}$ & $83^{\circ} 16^{\prime} 40,10^{\prime \prime} \mathrm{E}$ & 24.6 & -2.98 \\
\hline YA 12 SED 41 & Calcar. nodules & Jurassic (J3) & $42^{\circ} 6^{\prime} 52,30^{\prime \prime} \mathrm{N}$ & $83^{\circ} 17^{\prime} 18,50^{\prime \prime} \mathrm{E}$ & 21.2 & -2.03 \\
\hline YA 12 SED 39 & Calcar. nodules & Jurassic (J2-J3) & $42^{\circ} 6^{\prime} 57,90^{\prime \prime} \mathrm{N}$ & $83^{\circ} 17^{\prime} 18,10^{\prime \prime} \mathrm{E}$ & 22.6 & -7.61 \\
\hline YA 12 SED 38 & Limestone & Jurassic (J2) & idem & & 20.1 & -3.16 \\
\hline YA 12 SED 37 & Limestone & Jurassic (J2) & idem & & 19.2 & -0.26 \\
\hline YA 12 SED 36 & Limestone & Jurassic (J2) & idem & & 18.5 & 0.20 \\
\hline YA 12 SED 34 & Limestone & Jurassic (J2) & idem & & 23.0 & 3.14 \\
\hline YA 12 SED 33 & Limestone & Jurassic (J2) & $42^{\circ} 7^{\prime} 3,37^{\prime \prime} \mathrm{N}$ & $83^{\circ} 17^{\prime} 7,09^{\prime \prime} \mathrm{E}$ & 17.7 & -0.37 \\
\hline YA 12 SED 1 & Limestone & Jurassic (J2) & $42^{\circ} 7^{\prime} 32,40^{\prime \prime} \mathrm{N}$ & $83^{\circ} 14^{\prime} 10,40^{\prime \prime} \mathrm{E}$ & 20.4 & -3.49 \\
\hline
\end{tabular}




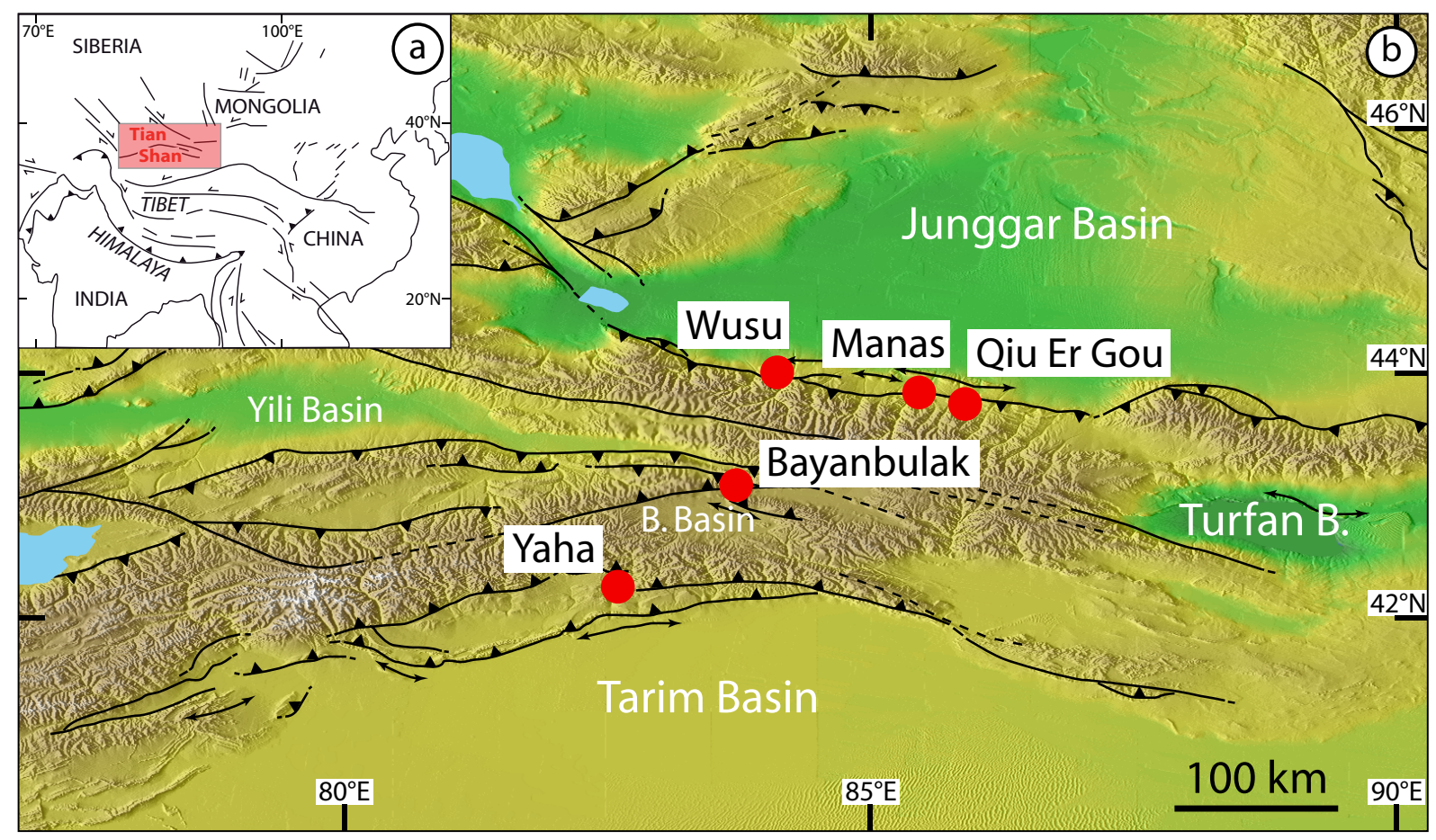

Heilbronn et al., 2014 - Fig. 1 


\section{Heilbronn et al., 2014 - Fig. 2}

$\mathrm{N}$

Junggar B.

Bayanbulak B. Tarim B. ${ }^{4}$

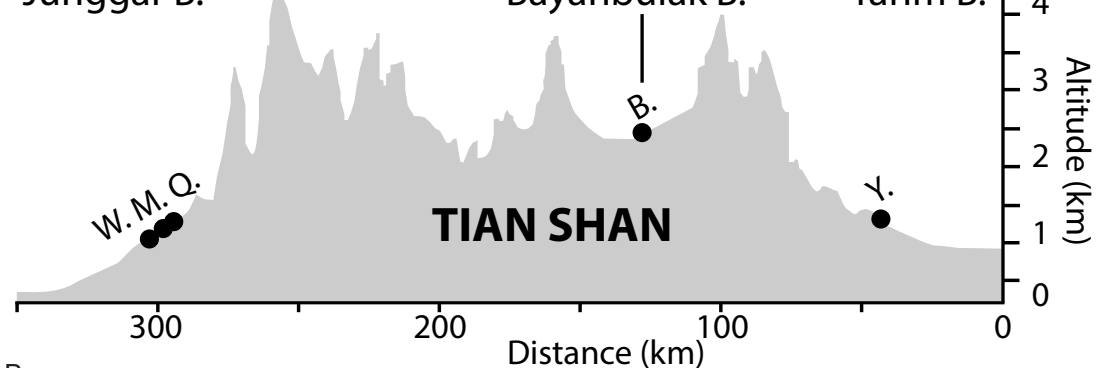

2500
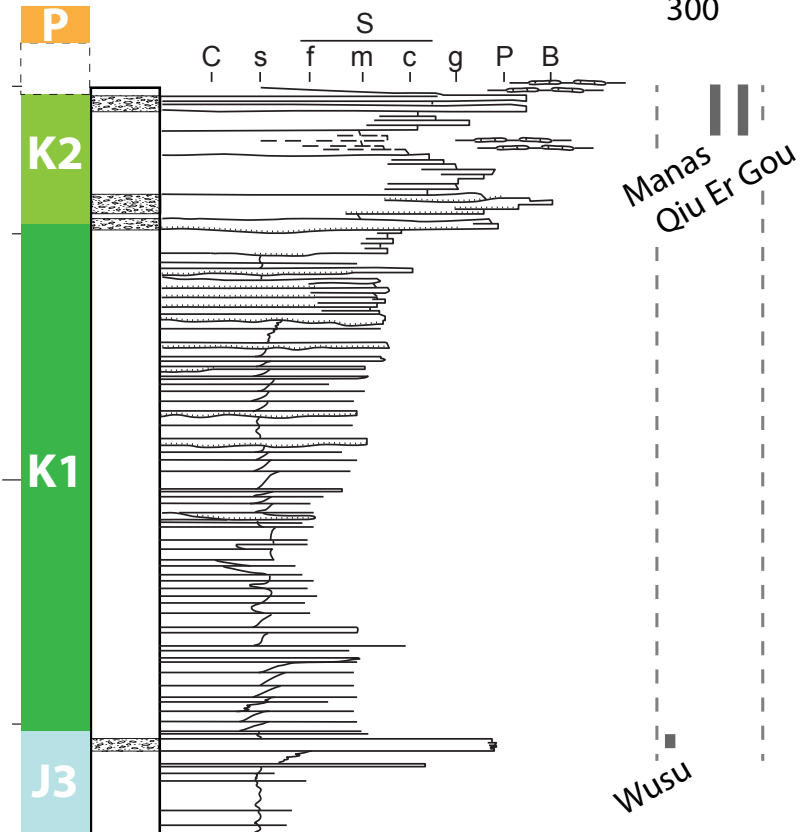

1500

2000

K1

1000
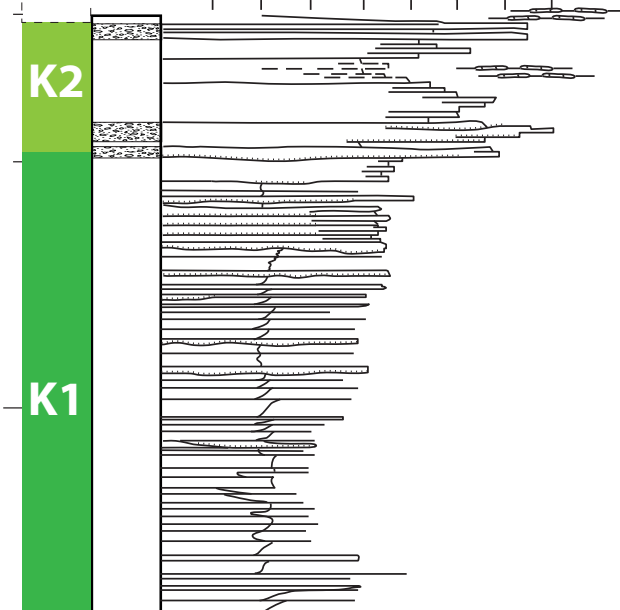

1500
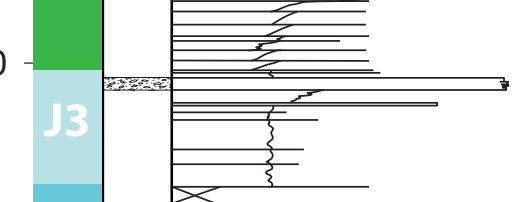

$\frac{<\sqrt{\frac{3}{2}}}{\sqrt{25}}$

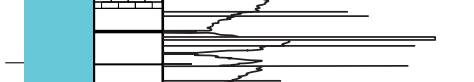

500

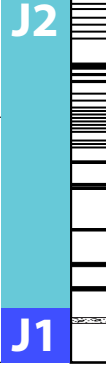

Nodule Calcrete (Nodule)

Nodule

Nodule

Nodule Limestone

Lithological column:

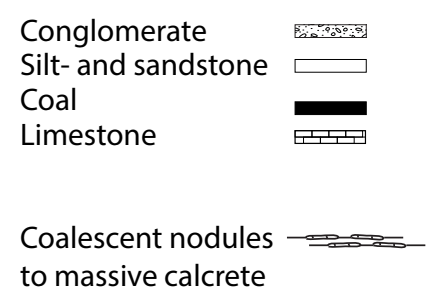

to massive calcrete 

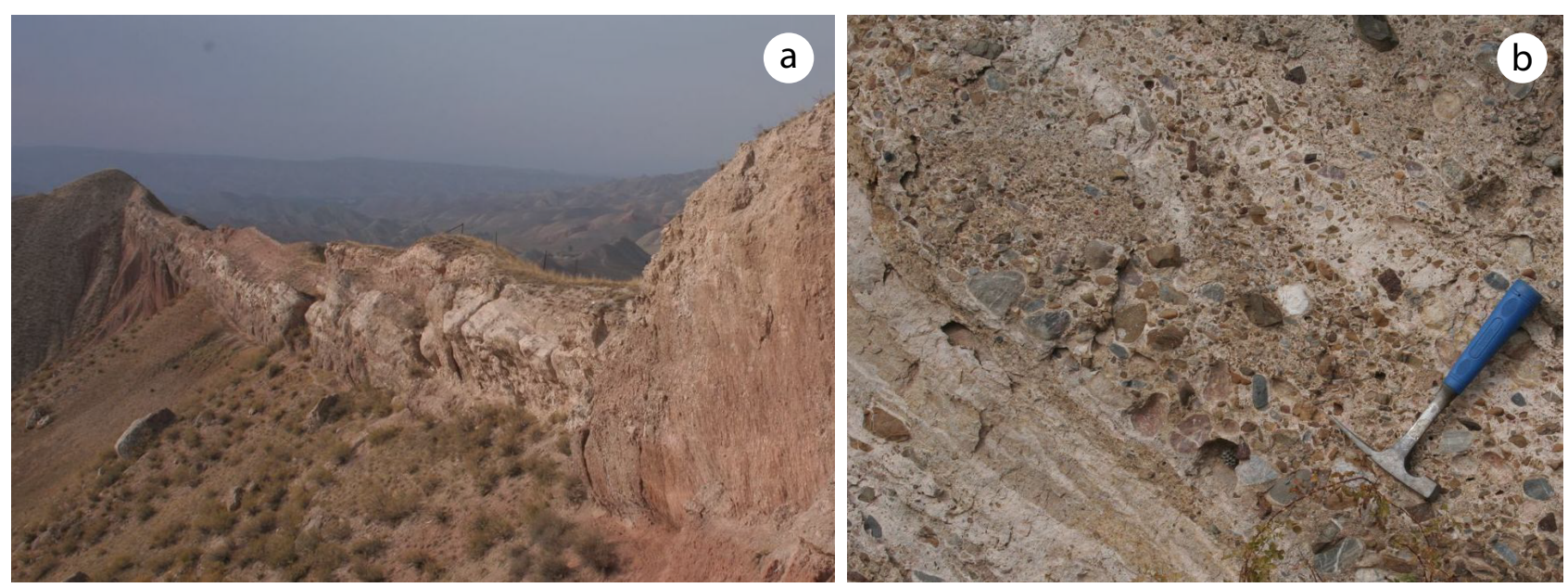

Fig. 3 - Outcropviews.
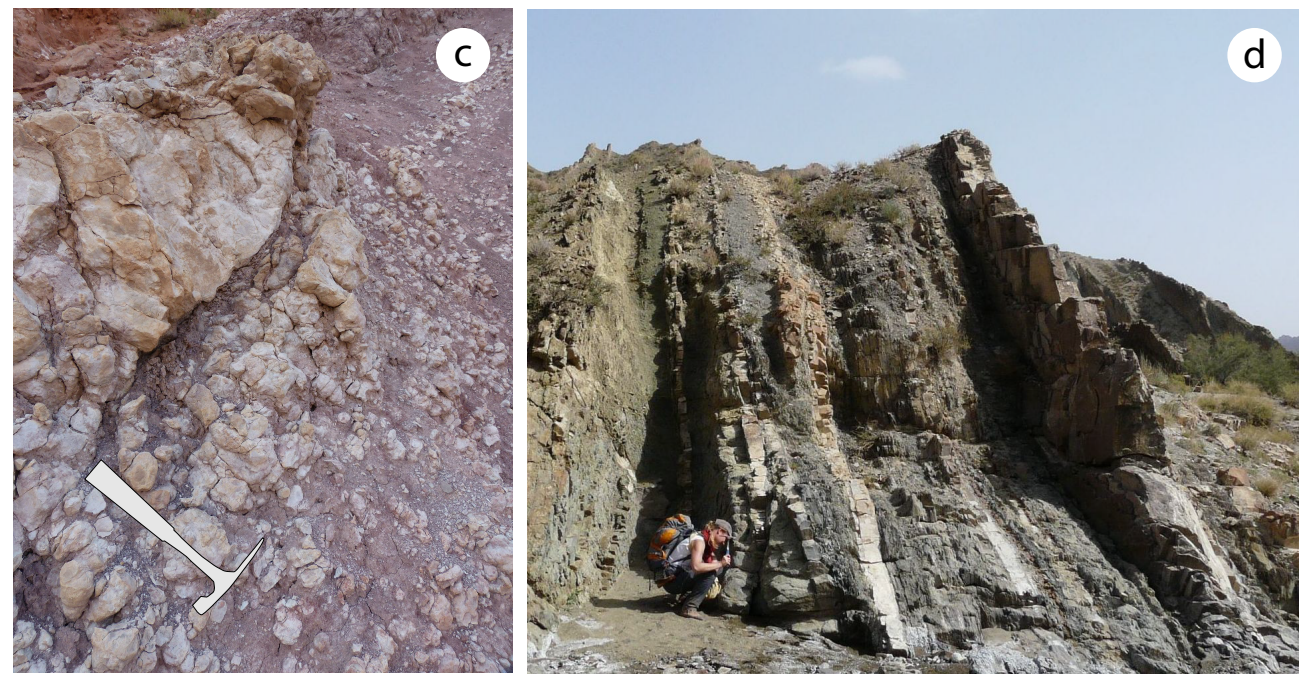

Heilbronn et al., 2014 - Fig. 3 

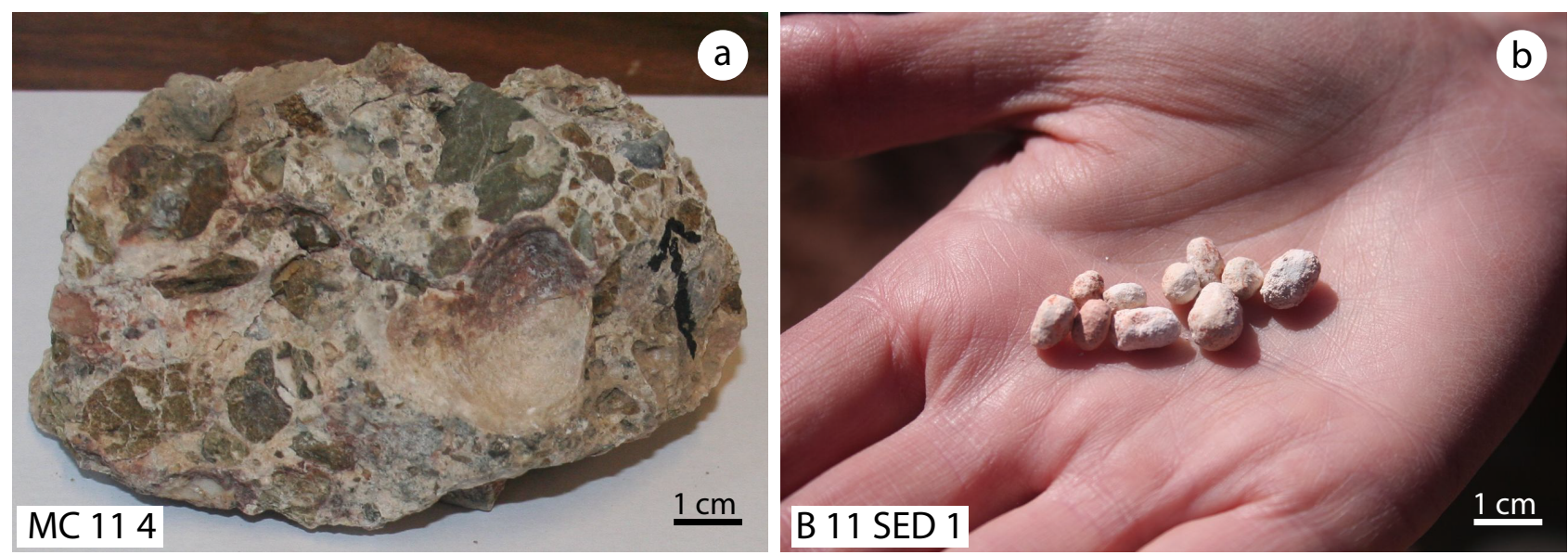

Fig. 4 - Examples of studied samples.

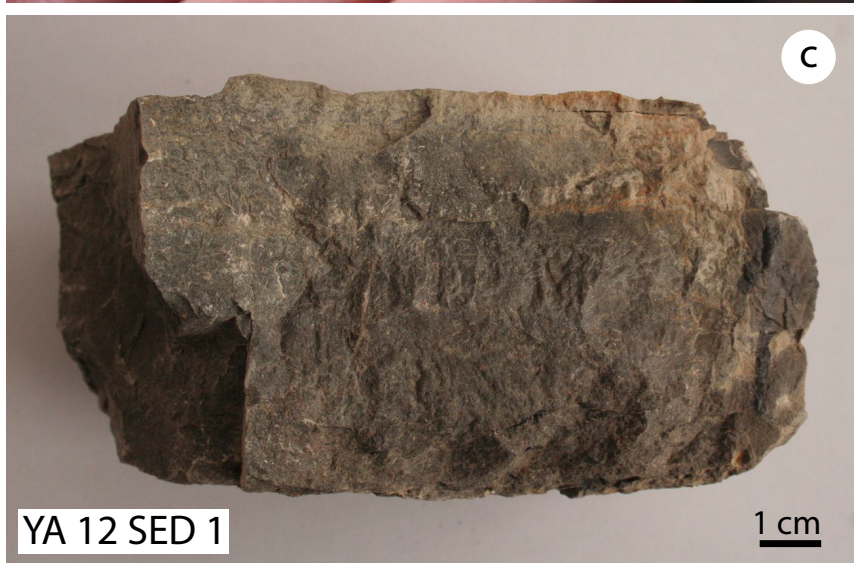

Heilbronn et al., 2014 - Fig. 4 

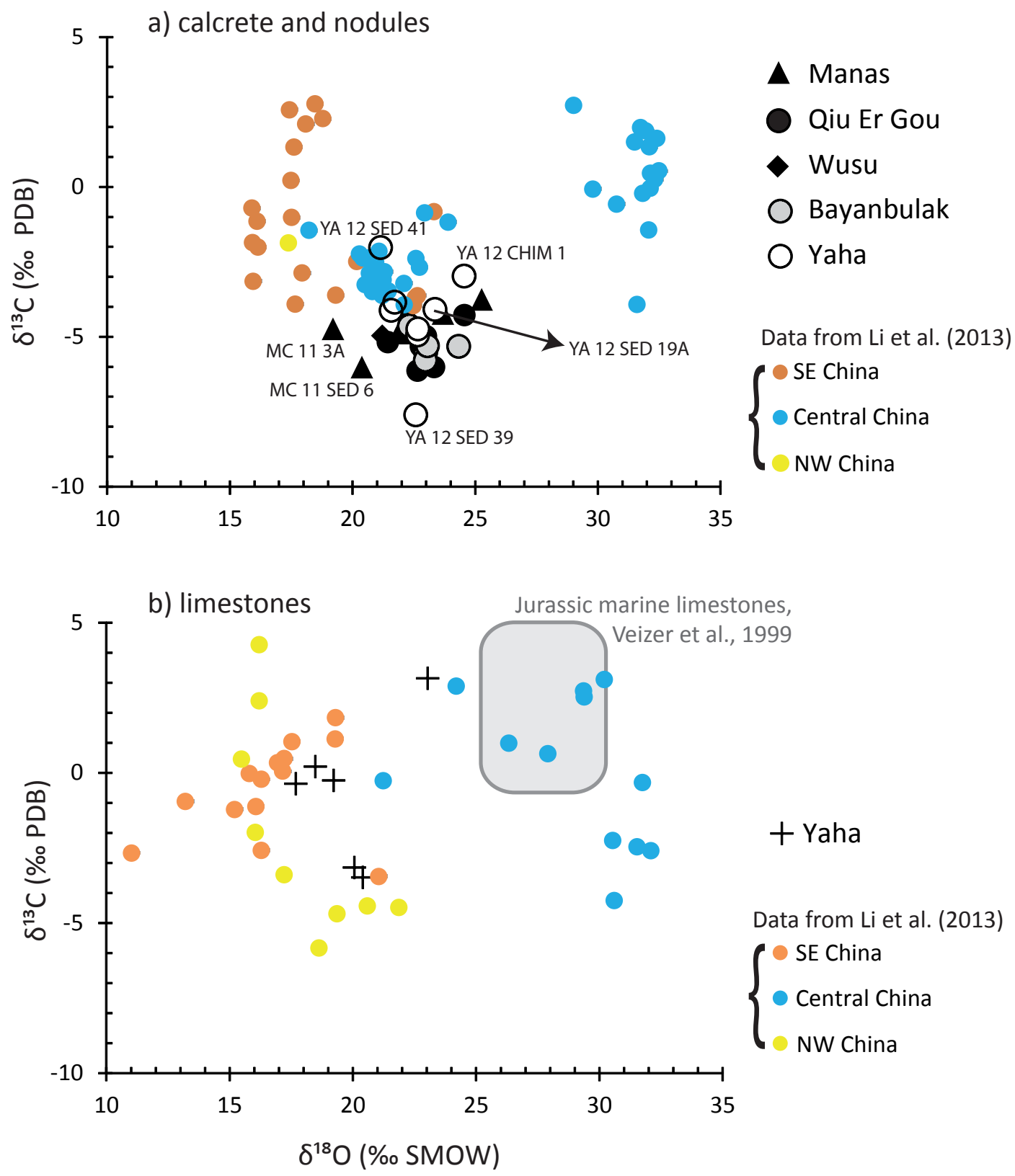

Heilbronn et al., Figure 5 